\title{
Legal Reconstruction: Ingsutan Paradigmatic on the Determination of the Positivism Paradigm and Legal Positivism in Law Enforcement in Indonesia
}

\author{
Unggul Basoeky \\ Universitas Diponegoro, Indonesia \\ Email: unggulbay@student.undip.ac.id
}

\begin{abstract}
Law as control should regard the reality, values and factors that determine every society's behaviour or action. As defined by the positivism and legal positivism paradigm, law enforcement should shift into a constructivist legal paradigm framework to reconstruct a more comprehensive law. Written law has a limited reach because it is quickly left behind by considering that the text of statutory rules is formulated in a different space and time than the current conditions. Through hermeneutic interpretation of the law, law enforcers are expected to understand every legal issue confined in legal texts and the context of the reality of the problem in depth. Law enforcers are guided by the methodology of legal discovery, which is driven by applicable laws and human behaviour. Every person who carries out every behaviour or action (actus) must be understood to the deepest or hidden layer, namely the subjective motivations behind his actions. Law enforcers must view reality as conceptual reality by making ideas as hypotheses to understand truth collectively and comprehensively.
\end{abstract}

Keywords: Legal Reconstruction, Constructivism Paradigm, Hermeneutics.

\section{A. INTRODUCTION}

This article discusses legal reconstruction in the form of a paradigmatic shift towards the determination of the Positivism Paradigm and Legal Positivism in law enforcement in Indonesia. Resolution of positivism and legal positivism often ignores the realities of life and values in society so that it gets various criticisms, rejection and distrust of law enforcement institutions. Law enforcement becomes dry and naive because legal regulations are read flat without meaning and essence. Public condemnation of every law enforcement drama that injures the public's conscience was portrayed in several cases, including Baiq Nuril and Fidelis Arie Sudewarto, and in fact, the alleged extra-judicial killing of six FPI soldiers by law enforcement officials. To restore the dignity and spirit of law enforcement, a legal construction is needed within the framework of the legal constructivism paradigm.

In Indonesia, law enforcement is always determined by positivism and legal positivism with the idea of legal certainty, especially legal certainty (legalism). Positivism permanently eliminates speculation about metaphysical aspects and the nature of law because the law is interpreted as something empirical, real, codified and systematic in statutory regulations (Zuliyah \& Triwahyuningsih, 2018). Determination of positivism implies that law enforcement officials only enforce the sound of the legal text instead of understanding the law in the context of social 
problems faced and developing in society (Rustamaji, 2015).

Even in the era of the Covid-19 pandemic, in a health emergency, the face of law enforcement in Indonesia cannot be separated from positivist determination (Lisdiyono \& Mulyani, 2021). Challenging conditions, exacerbated by the increasing crime rate, are often out of sync in formulating written law and policymaking at both the central and local government levels. Asynchronous law enforcement that does not heed the understanding of the social context of society will undoubtedly lead to irregularities, abuse and, of course, have ominous implications for the social order in society (Tamanaha, 2001).

Law enforcement seems to lose its spirit/soul because it is closed in deductive reasoning (Sinaga, 2018). All facts are analysed only based on legal norms/rules and legal doctrine, which are also the only significant premises and guidelines in formulating conclusions on all empirical facts. Interpretation in the syllogism is like in an iron cage because the answers (conclusion) are quietly available in the central premise (Tyesa \& Saraswati, 2020).

Of course, all people hope that law enforcement will not become a perennial problem that is impossible to eliminate. Therefore we need a paradigmatic shift from law enforcers in seeing the legal issues they handle. A basic set of belief is required, namely awareness and understanding not just applying laws but understanding law as interpretations or processes of interpreting and direction as it is inhuman actions and interactions (Prasetyo, 2020). Law is no longer understood as texts but is a symbolic meaning resulting from interpretation (both individually and collectively) as manifested in and from community action and interaction (Utami, Suteki, Saraswati \& Budiono, 2018).

\section{B. RESULT AND DISCUSSION}

\section{Determination of the Positivism Paradigm and Legal Positivism in Indonesia}

Determination in the Big Indonesian Dictionary (KBBI) is about determining, determining, ensuring. According to the Collins Dictionary of Law, a determination is "the termination of an estate or interest. the decision reached by a court of justice on a disputed matter". In legal use, determination usually implies the conclusion of a dispute or lawsuit by the rendering of a final decision. After consideration of the facts, a determination is generally set forth by a court of justice or another type of formal decision-maker, such as the head of an Administrative Agency. Determination has been used synonymously with adjudication, award, decree, and judgment. A ruling is a judicial determination concerning matters, such as the admissibility of evidence or a judicial or administrative interpretation of a statute or regulation. Determination in legal terms is a synonym for adjudication, decision, decision and judgment, which is usually the conclusion of a dispute or legal claim in the form of a final decision determined by a court or other formal decision-makers government or state administrative body.

Paradigm, etymologically, is "paradeigma", which comes from Greek, which is 
a combination of the words para (beside) and sigma (to see). Paradigm is also understood as a "Thinking Construction", which includes beliefs and standards, determines the scope of everything that is considered valid in a field (Chalmers, 1982), and defines a steady and steady pattern of scientific activity for the scientific community concerned (Jhonston, 1986). Paradigm is a central philosophical system built from ontology, epistemology, and methodology. Each consists of a series of fundamental beliefs or world views that cannot be exchanged with fundamental beliefs or worldviews from ontology, epistemology, and other paradigm methodologies. Paradigm is not just a theory but includes various components of scientific practice, including the standard definition of the required accuracy, the accuracy of research methodology, and how research results will be interpreted (Roman, 1998).

The ontological aspect concerns the nature of both the form and nature of reality, epistemology concerns the heart of the relationship or relationship between an individual or community group and the environment or everything outside of itself, including the object of research, which is something that is known (Widowati \& Wijayanta, 2020). It also contains axiology, namely concerning the purpose of knowledge. The methodology is how individuals or groups of people get answers to what they want to know in obtaining knowledge (Sulistyawan, 2019).

The Basic Belief Set of Positivism Paradigm is formed from ontology in Naif realism, an external, objective, accurate and understandable reality. Epistemology is in the form of dualism/objectivity, with the methodology being experimental/manipulative, empirical testing and verification of research questions and hypotheses, manipulation and control of opposing conditions, especially quantitative methods. The relationship between the positivist research group and the object of investigation are two independent, value-free entities. The purpose of the inquiry is an explanation, namely prediction and control of phenomena with the nature and meaning/content of knowledge, which is a hypothesis that has been verified and accepted as fact or law. Accumulated knowledge, namely accretion (growing gradually), every point (including the possible) is a building block for the building of ever-growing knowledge, generalisations and causal relationships for prediction and control. It is valued or value-free. The role of adherents or experts with special privileges, scientists who are interested and distanced, informers for decision or policymakers and change agents. Proponents of the positivism paradigm eventually became the source of logical positivism and legal positivism, namely a group of thought and streams with different patterns and models of reasoning (Zuliyah, 2019).

It moves on from the collapse of the teachings of natural law and the entry of the era of humans who prioritised rationalisation in examining the fields of life, or a period known as the enlightenment era. Actual as science is a natural science, something that is considered valid is collecting facts obtained through observations measured and seen continuously. Francis Bacon, Rene Descartes said that to recognise natural objects, they must be examined impersonally apart from subjective 
values and only based on reason (ratio) and freely observed experience, distance pairs, and impersonal (Adji, 2015).

The legal system in Indonesia cannot be separated from the history of legal science in Europe in the seventeenth century, especially in ending the dichotomy of empiricism and rationalism. According to Immanuel Kant, this dichotomy should not have occurred because both should compliment and complement each other. Rationalism emphasises the form (formal) and empiricism, highlighting the content (material), so these two things should be needed to build a science. From these two things, Kant made a critical philosophy based on "Thought without content is empty, intuition without concept is blind." Content or intuition is about empirical data, while concepts are thought-forms (Tommy, 2013).

According to Kant, humans are imperfect human beings because humans always act influenced by irrational craving or impulses (such as being "forced" to work according to norms just because of being watched or afraid of being punished). Therefore, the objective principle should not be imperative but obligatory because it becomes a commandment of reason (gebot der Vernunft). What is practically good is what determines will from an objective viewpoint, not on subjective grounds. These imperatives are only formulas to express the relationship between the aim rules of determination (Wollen) and the imperfections of human will (Lili, 1991).

In the end, Kant's thought gave rise to a flow that married rationalism and empiricism, namely positivism. This flow later became the source of the birth of legal positivism. Positivism itself was first developed by Auguste Comte (1798-1857). This figure is known as the originator of the Three Stages Law. This thought of Auguste Comte is claimed to be a "bridge" between Descartes' rationalism and Bacon's empiricism. The definition of "positive", according to Comte, consists of several possibilities, namely (Koento, 1996):

a. As the opposite or the opposite of something imaginary, the meaning of "positive" is first defined as the characterisation of something valuable. This is following his teaching, which states that the philosophy of positivism, in investigating its target object is based on the ability of reason, while things that cannot be reached by reason are not subject to investigation;

b. As the opposite or the opposite of something vain, the meaning of "positive" is defined as the signification of something valuable. This is following his teaching, which states that everything must be directed towards achieving progress in the philosophy of positivism. Philosophy does not stop at fulfilling the human desire to acquire knowledge or understanding of something;

c. As the opposite of something doubtful, the meaning of "positive" is defined as the signification of something specific. This is following his teaching, which states that philosophy must arrive at a logical balance that is good for every individual and society;

d. As the opposite or the opposite of something obscure, the meaning of "positive" is defined as the signification of something clear or precise. This is 
following his teaching, which states that in philosophical thinking, we must be able to provide a clear or accurate understanding, both about visible symptoms and what we need, because the old way of philosophising only provides unclear guidelines and only maintaining the necessary discipline based on supernatural powers;

As the opposite or the opposite of something negative, the meaning of "positive" is used to show the characteristics of his philosophical view, which always leads to ordering or ordering. In the law of three stages, Comte states that man develops in the direction of progress, not only in the historical process of his life but also in the development of his soul. The three stages consist of: (a) the theological or fictitious stage, (b) the abstract metaphysical stage, and (c) the natural or positive stage. According to Comte, the positive stage society is the ideal society.

The development of the positivism paradigm, almost penetrating all sciences, both science, social science and even legal science, has had a similar effect. Legal Positivism or Legal Positivism is a flow of legal philosophy that defines law as what is written in the books, namely favourable rules that apply in abstracto at a particular time/place. Legal positivism describes the law as Ius Constitutum, namely existing and applicable laws, published law as an explicit product of a specific legitimate source of political power. The law is manifested as clear commands that have been positively formulated to guarantee certainty, such as statutory regulations, which applies nationally in a country. For this reason, it can be said that the operation of the legal positivism flow is based on positive legislative norms from the positive normative realm (McCourbey \& White, 1993).

The description of the legal positivism understanding above is a definition put forward by H.L.A Hart, that "The expression "positivism" is used in contemporary Anglo-American literature to designate on or more of following contentions : (1) that laws are commands of a human being; (2) that there is no necessary connection between law and morals, or law as it is and law as it ought to be; (3) that the analysis or study of the meaning of legal concepts is an important study o be distinguished from (though in no way hostile to) historical inquiries sociological enquiries and critical appraisal of law in terms of morals, social aims, functions; (4) that a legal system is a closed logical system in alone; (5) that moral judgements cannot be established, a statement of fact can help by rational argument, evidence or proof (non-cognitivism in ethics)" (Hart, 1961). Law is a human order to have a closed logic system. Law is separated and has nothing to do with morals with concepts distinguished from historical inquiry and sociological questions, critical judgments of law about morals and social ends and functions.

Other figures who embrace legal positivism are John Austin through the law of will (The Will Theory of Law) and Hans Kelsen through Pure Law Theory (The Pure Norm Theory of Law). According to John Austin, "A positive legal rule is to be equated with the expression of an act of wishing," and "the legal system is to be equated with all the positive legal rules emanating from the same sovereign will". According to the teachings of John Austin (1790-1859), the law must be manifested in a written form made by an institution that has the authority and is legally 
authorised. The authorised institution is a sovereign state. Based on its sovereignty, then the state can make legal rules. He continued, in relations between countries, or as an external aspect, governments have the authority to compile international law, while as an internal aspect, each country has the power to collect national law. John Austin introduced the term analytical jurisprudence to refer to legal teachings developed from the positivism school.

The term analytical jurisprudence indicates that in law, science must be separated from metaphysical studies. In analytical jurisprudence, all intellectual activity has one characteristic, namely that it cannot leave the realm of positive law, and in the late nineteenth century period it was marked by modern legal science, where law science must meet the requirements/criteria of science, namely:

a. Value-free, in the sense of being free from interests, values, and emotions to obtain objective knowledge.

b. Science must use empirical verification methods.

c. Reality is reduced to observable facts.

Positivistic thinking in law has given rise to a school of jurisprudence called formalism or conceptualism. The primary purpose of legal formalism, according to Herman J. Pitersen, is to build legal principles, a comprehensive and strict preposition of justificatory structure on legal practices with logical deductive natural science methods, without the help of other disciplines such as philosophy or social science (Adji, 2010).

Meanwhile, according to Kelsen, "A positive legal rule is to be equated with a pure norm, that is with an ought or may meaning content. The legal system is to be equated with a collection of pure norms interpreted by legal scientists as a non-contradictory field of meaning such interpretation entailing the logical postulate that legal norms must originate in a finite number of source".

A set of norms arranged systematically is a formulation that becomes the source of legal discovery activities for law bearers. The validation of a model is studied from a hierarchical system of positive norms. Adherents of legal positivism are in a neutral position towards the community as the party being researched. They have a special privilege and usually behave like scientists who have no interest or distance from society both as objects of research and as objects of law itself; the law is believed to be value-free.

The axiological aspect that legal positivism strives for is legal certainty. By taking a formal source of law in the form of legislation, it is believed that this can be realised. The principle of legality is the spirit of the pursuit of legal certainty. Von Feuerbach formulated this principle in the adage "No punishment without law, no punishment without crime, no crime without punishment" (nulla poena sine lege, nulla poena sine crimine, nullum crime sine poena) (Bambang, 1992).

Thus, adherents of the positivism and legal positivism paradigm understand that law must be value-free, interest-free and based on empirical and objective knowledge. To guarantee legal certainty, then the direction is positive in the form of a written legal codification in statutory regulations stipulated by a legal institution 
and has the authority. The statutory regulations are made in a generally understood, rigorous formulation and arranged in a systematic manner that is mutually compatible. This rule contains rights, obligations and sanctions for anyone who commits an offence without exception.

The method of legal interpretation used by law enforcement officials is systematic interpretation, that is, a material containing articles in law and its explanation is absolute legality which cannot be interpreted differently through an understanding. Legal actors place themselves in a legalistic, positivist and role bound way of thinking and understanding the law, which studies law only in the outward aspect, not touching the values or norms that arise from social realities such as justice, truth, wisdom that usually underlies rules. - legal regulations that do not have a place because they cannot be reached by sensing (Erwin, 2007). The positivism paradigm, better known as the positivism philosophy, ultimately determines law enforcement at the police, prosecutors, courts, and government levels.

For clarity, the reasoning pattern of Legal Positivism can be formulated with the following examples:

a. Positive norms in Article 39. Article 6 paragraph (1), in conjunction with Article 45 paragraph (1), Government Regulation No. 9 of 1975, establishes a structure of rules which in this example assumes that the norms have been validated (fulfilling the principles of exclusion, subsumption, derogation, and non-contradiction).

b. Once upon a time, there was a marriage between widow A and Mr B, which was supervised and recorded by a marriage registrar named $C$.

Normative premise: (1) Waiting time for a widow, if the marriage breaks up due to death, the waiting time is applied to 130 (one hundred and thirty) days (Article 39 paragraph (1) letter a PP a quo); (2) A registrar who receives the notification of the intention to enter into marriage, examines whether the conditions of the marriage are fulfilled and whether there is no marriage obstacle according to the law (Article 6 paragraph [1] PP No. 9 of 1975); (3) Marriage Registration Employees who violate the provisions in Article 6, This Government Regulation is punishable by a maximum imprisonment of 3 (three) months or a maximum fine of Rp. 7,500, - (seven thousand five hundred rupiahs) (Article 45 paragraph [1] letter b PP 9 of 1975).

Fact: Mrs A was a widow whose husband died on January 1, 2003, and she married Mr B on May 1, 2003. The marriage registrar named C, who supervised and registered the marriage, was threatened with imprisonment.

If we look at the structure of the rules in these normative premises, it can be seen that there is a policy to state that marriage should not be carried out during the iddah period. The consequences of taking place during the iddah period did not result in the union being cancelled automatically. Article 27 paragraph (1) PP No. 9 of 1975 states: If the marriage has taken place then it turns out that there is a prohibition according to the law on marriage or rules and regulations regarding 
marriage, the Religious Courts can cancel the wedding at the request of the parties as referred to in article 23 of Law No. 1 of 1974.

The parties referred to in Article 27 paragraph (1) above according to the provisions of Article 23 are: (1) families in the straight line of descent from husband or wife; (2) husband or wife; (3) the official who is authorised only as long as the marriage has not been decided. (4) the official referred to prevent the marriage from taking place and everyone who has a direct legal interest in the marriage, but only after the marriage has broken up. Article 27 and Article 23 must also be included in the regulatory structure along with other relevant provisions.

From the viewpoint of Legal Positivism, if we refer to the case above, spouse A and B's marriage does not automatically become null and void. Cancellation is only possible if there is a request from certain parties stipulated by law. In a positive direction, the result is more emphasis on marriage registration employees. If it is proven that it has not carefully examined these conditions, it is the Marriage Registration Officer who will be subject to punishment. Threats to A and B are not defined in positive law unless they have proven that they intentionally provided false information. If the case structure is discretised, the following formula will appear:

\begin{tabular}{|c|l|}
\hline PJq & $\begin{array}{l}\text { If a marriage registrar does not examine the conditions of } \\
\text { marriage, including the iddah period), he will be subject } \\
\text { to imprisonment or a fine. }\end{array}$ \\
\hline $\mathrm{P}$ & $\begin{array}{l}\text { Marriage Registrar } \mathrm{C} \text { does not examine the period of } \\
\text { iddah in the marriage between } \mathrm{A} \text { and } \mathrm{B} . \text { Marriage } \\
\text { registrar C is subject to imprisonment or a fine. }\end{array}$ \\
\hline$\cdot . \mathrm{q}$ & Marriage Registry Officer C faces imprisonment or a fine \\
\hline
\end{tabular}

This conclusion (.. $\mathrm{q})$ is a standpoint that is built based on arguments in the form of propositions on it. To borrow Hans Kelsen's perspective, proposition $\mathrm{p}$ is the primary norm and $\mathrm{q}$ is the secondary norm. The relationship between these two norms is unique, which at the same time shows the uniqueness of legal reasoning. In contrast to reason in the exact sciences, the compound proposition $\mathrm{P} q$ is not based on a causal relationship. The relationship is accountability (zurechnung) (Maria, 1998). There is an essential principle in criminal law that people are not punished if there is no mistake (geen straf Zonder schuld). This error element must be proven so that without it, the threat formulated in the secondary norm (q) cannot be held accountable to the C Marriage Registration Officer.

Law enforcement on Baiq Nuril and Fidelis Ari Sudawoto is a portrait of law enforcement characterised by positivism. The facts of the events experienced by Baiq Nuril are reduced empirically, and from these facts, the fault of his actions is sought so that penalties can be applied as stipulated in the prevailing laws and regulations. In the end, Baiq Nuril was found guilty and sentenced to serve a prison sentence of six months and a fine of Rp. 500 million, a subsidiary of three months in prison 
according to the Supreme Court decision.

The reasoning pattern in making the verdict against Baiq Nuril is as follows:

\begin{tabular}{|c|l|}
\hline PJQ & $\begin{array}{l}\text { If any person knowingly and without rights distributes and } \\
\text { transmits and causes access to Electronic Information and } \\
\text { Electronic Documents that have contents that violate decency, } \\
\text { he will be threatened with imprisonment and a fine; }\end{array}$ \\
\hline P & $\begin{array}{l}\text { Baiq Nuril knowingly and without right distributes, transmits } \\
\text { and makes IE / DE accessible; Baiq Nuril faces imprisonment } \\
\text { and a fine; }\end{array}$ \\
\hline$\therefore \mathrm{q}$ & Baiq Nuril was threatened with imprisonment and a fine \\
\hline
\end{tabular}

The guilty verdict against Baiq Nuril was based on an error, and the elements listed in the provisions of Article 27 paragraph 1 in conjunction with Article 45 of the ITE Law were fulfilled, among others:

a. Everyone's element; Baiq Nuril is a person who can be presented and answer any questions given by the Panel of Judges

b. Element "intentionally and without the right to distribute"; carried out by Baiq Nuril by giving the recording because the witness Haji Imam Mudawin asked continuously for recorded conversations to be used as material for reports to the Mataram DPRD, which resulted in Baiq Nuril handing over his cellphone containing the recorded conversation.

c. Electronic Information Elements and or electronic documents;

d. The elements of content violate decency;

The rejection of the legal review (PK) that was submitted to the Supreme Court as well as agreeing with legal considerations in the previous Supreme Court decision which stated that the conviction of Baiq Nuril could be a lesson for the defendant and especially for the public in general so that they can be more careful in using and using electronic media involving a person's data or interpersonal conversations, the use of which must be with the consent of the person concerned. This decision was said to be very ironic, hurtful and tended not to protect women because considering what Baiq Nuril had done was a form of resistance to attempts at sexual harassment by his superiors.

Not only the Baiq Nuril case, the irony of the portrait of law enforcement in Indonesia which is determined by the positivism paradigm, also occurs in the case of Fidelis Arie Sudewarto, who was arrested by the National Narcotics Agency (BNN) for planting 39 cannabis trees (Cannabis sativa) for the treatment of a wife's cancerous cyst. Spinal cord. Fidelis was found guilty of eight months in prison, and Rp. 1 billion subsides one month.

The reasoning pattern in deciding against Fidelis is as follows:

Any person who without right or against the law uses Narcotics Category I against other people or gives Narcotics Category I for the use of other people shall be punished with imprisonment for a minimum of 5 (five) years and a maximum of 15 
(fifteen) years and a fine of at least Rp1,000,000,000.00 (one billion rupiahs) and a maximum of Rp.10,000,000,000.00 (ten billion rupiahs) (Article 116 (1) of Law No. 35 of 2009);

\begin{tabular}{|c|l|}
\hline PЭQ & $\begin{array}{l}\text { If every person without rights or against the law uses Narcotics } \\
\text { Category I against other people or gives Narcotics Category I for } \\
\text { the use of other people, he will be threatened with imprisonment } \\
\text { and a fine; }\end{array}$ \\
\hline $\mathrm{P}$ & $\begin{array}{l}\text { Fidelis, without rights or against the law, gave Class I narcotics } \\
\text { to be used by his wife as treatment, Baiq Nuril was threatened } \\
\text { with imprisonment and a fine; }\end{array}$ \\
\hline$\therefore \mathrm{q}$ & Fidelis faces imprisonment and a fine \\
\hline
\end{tabular}

The Panel of Judges at the Sanggau District Court found Fidelis guilty because his actions were proven guilty and fulfilled the elements in Article 116 (1) of Law Number 35 concerning Narcotics among others:

a. Everyone's element; that Fidelis can be proven to answer all the questions posed firmly during the trial.

b. Elements without rights or against the law, considering the provisions of article 7 of the Narcotics Law that narcotics can only be used for the benefit of health services and / or development of science and technology, while article 8 states explicitly the prohibition on the use of Class I Narcotics, namely: (1) Narcotics Category I is prohibited from being used for the benefit of health services, (2) in limited quantities, narcotics group I can be used for the purposes of developing science and technology and for diagnostic reagents, as well as laboratory reagents after obtaining the approval of the Minister on the recommendation of the Head of the Food and Drug Administration; (3) Using class I narcotics against other people or giving class I narcotics for use by another person; Whereas the elements above are alternative, meaning that to declare someone guilty of committing a criminal act in that article does not have to be proven that all the acts were committed by the perpetrator but it is sufficient that one of the acts was proven to have been committed. Then the elements above are considered completely fulfilled;

c. The element of using narcotics, considering that what is meant by using drugs can be interpreted as entering into the body either directly or by mouth or by using a supporting device;

The judge considered that the act of growing marijuana by Fidelis was wrong and that the sentence was handed down as a deterrent effect so that the general public did not follow Fidelis' treatment method. The law must be released from human values; even though the mistake is an effort to help the safety of human life, the knife of the law must be sharp to stab anyone indiscriminately. In this case, the law seems to be an angel of death to human life. 
Observing the judge's decision on Baiq Nuril and Fidelis Arie, it can be concluded that law enforcement in Indonesia illustrates the determination of the positivism paradigm, which results in the law being very legalistic. Facts in the social life of society are reduced to observable facts, and they are always looking for mistakes so that legal elements can be applied that can punish these actions. Valuefree favourable laws can only be read flatly without trying to find the essence of the law, which should be a condition of meaning and values. The role of law enforcers is limited by distance, free from interests and emotions to obtain objective knowledge. The law must be separated from moral arguments; thus, the legal discovery methodology carried out by law enforcers and experts is always guided by the applicable law as a product of authorised power that contains explicit orders that are positively formulated in statutory regulations. In the end, law enforcement officials tend to make the law a primum remedium so that the law has the potential to be applied excessively (overspanning van het straftrecht). The law should be the "final remedy" (ultimum remedium), as the previous sanction to be used when other sanctions are deemed insignificant.

\section{Ingsutan Legal Paradigm with Legal Constructivism Modeling}

In the style of the State Pancasila, which contains ethnic and cultural diversity, to uphold social values, law enforcement in Indonesia, especially law enforcers, must be shifted (ingsut) from understanding positivism law to understanding the constructivist legal paradigm-moving from a value-free, interest-free, empirical and objective knowledge-based understanding of the law to understanding law as interpretations or processes of interpreting, the law as it is inhuman actions and interactions. Law is symbolic meanings resulting from performance manifested in and from community action and interaction. Law works in interactional symbolism. Law is a mental construction that is relative, plural, diverse, intangible, local and specific - although similar elements can be found in individuals, groups of people, or different cultures, these mental constructions are built through the experience of human life, starting from life. Personal, family, community, nation, state to interstate life.

Reconstruction, revision, or change of law occurs continuously, in line with enrichment of information and sophistication or creation of the feelings of the people themselves. So the existing law is a consensus, agreement or relative resultant among various understandings, opinions, or opinions regarding the problem at hand, according to the context of space and time.

The ontology of legal constructivism philosophy of law is relativism, where the law is interpreted as a pluralistic and at the same time diverse reality. Law is formed based on the social-individual experience, which is local and specific. The epistemology of legal constructivism is transactional or subjectivist. Humans, human groups and institutions about law take place in intensive and extensive interactions. Law is created or constructed jointly by all interested parties without denying their respective subjectivity to the methodology of making, forming, developing, or 
enforcing the law through hermeneutical and dialectical.

Legal construction is formed through interactions between lawmakers and law enforcers and the broader community as legal objects by applying hermeneutic techniques and dialectical exchange. The aim of this whole process of both lawmaking and enforcement is ultimately to achieve distillation, consensus, or the results among the various constructs of different origin (Guba \& Lincoln, 1994).

Investigation or research on law and problems society faces aims to understand the law in social issues that develop in the community. Research or analysis is directed to reconstruct existing legal constructs. However, the consensus / resultant legal construction remains open to new interpretations as information and sophistication develop. The revision or reconstruction of each of the existing buildings will take place on an ongoing basis. Reconstruction occurs when various constructs are at a juxtaposition in a dialectical context.

Legal constructivism recognises and values, history and community empowerment. Legal experts, practitioners and observers were seen as passionate participants, facilitators of multivoiced reconstruction, as well as orchestrators. As an illustration, the paradigmatic shift from positivism determination to constructivism is as follows:

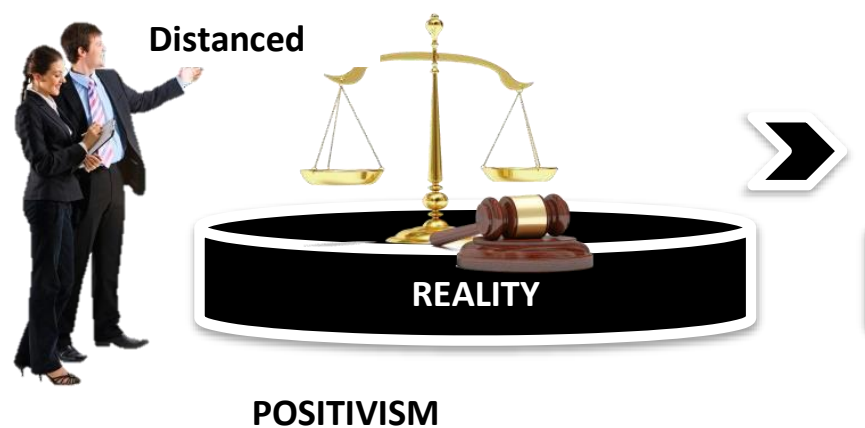

POSITIVISM

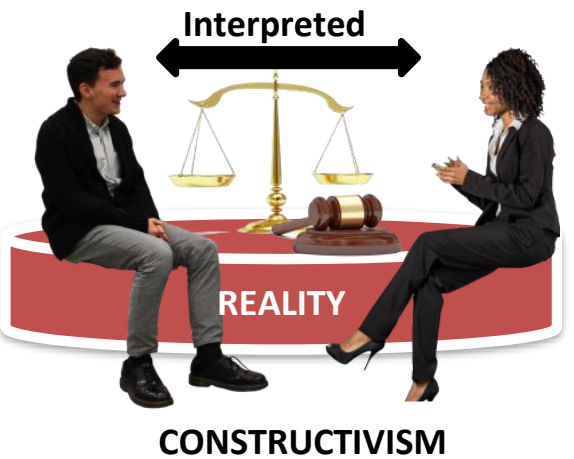

CONSTRUCTIVISM

Whereas the consequence of written law is that each statutory regulation has congenital disabilities and human-made defects resulting in limited reach, it is quickly out of date compared to society's rapid development and change (Ridwan, 2017). In this way, the law should be a much needed social control instrument. The relationship between law and social change is an interactive relationship that there is a reciprocal effect where changes in the legal sector and social changes affect each other. The faster the law responds to the voice of change in society, the more significant the role of law in changing society, but the slower the law responds to changes in society, the smaller the role and function of law in changing culture (Nazarudin, 2017).

Law becomes alive in people's lives through understanding and interpreting to be used and enforced. The theory that talks explicitly about interpretations are hermeneutics. Hermeneutics has developed since ancient Greece, which was later popularised by Schleiermacher, Wilhelm Dilthey, Martin Heidegger, Hans-Georg Gadamer, Paul Ricoeur, Jacques Derrida. Hermeneutics comes from the word 
"Hermes", is a god in Greek mythology whose job is to convey or interpret messages from the gods to humans.

Hermeneutics is a method used to interpret the text to avoid the reader/interpreter from a misunderstanding in finding objective meaning with a correct approach (Hermansyah, 2009). In its development, hermeneutics has developed into a scientific discipline that changes the way of the view of the object of conversation so that several hermeneutic paradigms are known, namely theoretical hermeneutics, philosophical hermeneutics and critical hermeneutics.

Theoretical hermeneutics, in terms of perspective, two things are necessary for academic hermeneutics, namely grammatical interpretation and then psychological interpretation. Grammatical is understood according to the author's intent, which is then understood the objective meaning of the text; this psychological interpretation psychologically, according to Schleiermacher, is a validation of grammatical understanding. This places the text at the time and place where it was composed and a logical reconstruction of meaning based on formal analysis and historical research and traces forming a text. The purpose of a text can only be determined by referring to the cultural field when the text was written. According to Schleiermacher, everyone can re-experience the internal process of the author of the text. Therefore the method of legal discovery, based on the text of legislation and doctrine, can be highlighted with a hermeneutical approach.

Philosophical hermeneutics emphasises new meanings and not reproducing initial intentions in seeing a text (Yudha, 2009). Philosophical hermeneutics in law is used to determine the lawmaker's intent from visiting the historical side of each statutory regulation. Through this interpretation, an understanding of social and political settling can be obtained, the birth of a statutory rule so that any historical meaning that will be tried to be actualised in the law enforcement process can be prevented from occurring "gaps". Meanwhile, critical hermeneutics emphasises extralinguistic factors as problems that must be solved without neglecting things outside of languages such as work and dominance that determine the formation of context and actions.

The Criminal Justice System is still dominated by theoretical and philosophical hermeneutics. Judges always try to find the objective and universal meaning of laws as a text or look for new purposes (reconstructions) to affirm the text (directions). Judges will never be willing and able to see other forces behind the text, either in the form of domination or ideology, so that their decisions cause public disappointment.

P. Winch defines understanding (verstehen) as the human ability to understand each other based on their own experiences. In connection with these principles, five basic assumptions are made (Wuisman, 1996):

a. Understanding is something familiar in everyday human life because, without interpretation of the actions of others, humans cannot act, namely directing their behaviour to achieve specific goals;

b. Behind the actions (actus), body movements (gesticulation), and speech are 
hidden signs, symbols or symbols, namely in the form of subjective impulses such as thoughts, ideas, feelings and hopes;

c. Humans can penetrate the "outer layer" (in the form of the previous signs) to the subjective impulses that lie behind it; This ability is because both the party whose action is understood and the party who wants to understand are both within the scope of shared experience

d. The power of human understanding is not only to highlight individual actions that are limited by time and space; the target of understanding can also reach a more comprehensive phenomenon; this complete phenomenon can be understood because, in essence, it is a human fact which is also based on the giving of meaning by the human being concerned;

e. Even if two strangers live in different historical contexts, they can still understand each other because both of them are part of a collective understanding that contains all the existing meaningful facts; this collective consciousness transcends individual consciousness; that is, it cannot just be influenced by a power thought each; but what one thinks is a mirror of meaningful general facts;

Dilthey's view has implications for the concept of truth and objectivity. According to him, truth is the existence of similarities with a general and comprehensive human collective understanding. This truth is essentially normative because collective wisdom is about the form in which humans should express themselves. Regarding objectivity, Dilthey stated that knowledge developed by the Verstehen method could only be objective if it meets three conditions, namely (1) driven by genuine interest; (2) the form of the object of study (the expression of human life) has been fixed and remains for an extended period, and (3) produced following the rules of making standardised interpretations to re-create the object of study in the scientist himself based on feelings of empathy for fellow human beings.

The hermeneutics in Dilthey's eyes operates according to two principles. First, the principle of inseparability between knowing something and valuing it. Two sides of the effort to develop an understanding (verstehen) are always connected because the fact that the human sciences learn is essentially normative, namely regarding the situation as it should be. Second, the principle of necessity links understanding efforts with a broad context for developing understanding. This means that knowledge can only be produced by linking specific and concrete things with more comprehensive and abstract things.

The Formal Logic Model of Critical Constructivism stems from knowledge problems, which arises in the researcher's mind. The idea of investigating this emerged because "empirical information" contradicted or deviated from the current understanding. Because his knowledge cannot provide a satisfactory explanation, the researcher tries to find or develop a new idea. These new ideas are open to testing through gathering practical information, the researcher and trying to show the untruth of the new concept. This is how it continues to be done to come to a broader and more complex research context. 
Critical constructivism departs from several assumptions: (1) there is no direct relationship between theory (scientific knowledge) and reality (empirical); (2) a theory cannot be proven inductively or empirically, it cannot simply be shown deductively: (3) what is called theory and empirical exists only in a "reality" which can only be "constructed" in mind, which then referred to as "conceptual reality"; (4) to develop scientific knowledge, theory and empiricism are challenged in a conceptual reality through a standard logical form in the form of an interpretation method; and (5) the interpretation is criticised, so that if it cannot be shown to be untrue, it will be accepted as scientific knowledge.

Wuisman gives a concrete example of Critical Constructivism in his research in the Rejang community (Bengkulu). Initially, he was surprised at the custom of the Rejang wedding ceremony, which always slaughtered the goats, but the number of goats was not always the same between one marriage. He asked several people about the reason. But their explanations vary. From this contradiction in practical information, Wuisman then constructs an idea in the form of a statement. He stuck to this idea temporarily while continuing to gather new empirical data. It turned out that he found that there was a wedding party that cut two goats attended by fewer invitations, while a party that cut a goat was filled with more invitations. The results of this collection of practical information bring him to Statement II. This result surprised him because it contradicted Statement I. This contradiction gave rise to new problems, so he sought additional empirical information. Sometime later, he learned from the Rejang people that the conflict could be explained as follows: if there is a violation of marriage rules, two goats are slaughtered, whereas if there is no violation, only one is slaughtered. Because Islamic religious rites dominate the marriage ceremony, Wuisman thought that such rules came from Islamic marriage law, so he came up with a new idea (Statement III).

This new idea seems to explain the difference in the number of goats being slaughtered and the number of guests. If there is a marriage that deviates from the rules of the Islamic religion, of course, the party concerned feels ashamed, and the guests who are invited or willing to come are also few. This Gageasan did not last long. Based on further empirical information, it is known that the violations discussed here occurred because of the marriage of a close relative, which is still permitted in Islam. Therefore, Statement III can no longer be maintained, so Wuisman has to look for new ideas again (Statement IV). According to the custom of the Renjang people, siblings who are descended from one "Poyang" are prohibited because they belong to the same "Poyang" group (even though Islam allows). For this ancestral group, exogamy rules apply, meaning that a mate must be sought outside the kinship group. If there is a marriage from the same ancestor (usually because of pressure), it is necessary to cut two goats. If it is exogamy, it means that a mate must be sought outside the marriage kinship group of different ancestors; it is enough to slaughter a goat. This is how Wuisman built critical constructivism. Continuously to answer the gap between the ideas he has in mind and the practical information he gets. 
Statements Constructed Through Critical Constructivism

\begin{tabular}{|c|c|}
\hline Statement & Formulation of Ideas \\
\hline $\mathrm{I}$ & $\begin{array}{l}\text { Marriage ceremonies among the Rejang people apply: if } \\
\text { there is a violation of the rules of marriage, two goats are } \\
\text { cut, whereas if there is no violation, only one is cut }\end{array}$ \\
\hline II & $\begin{array}{l}\text { For the marriage ceremony among the Rejang people, the } \\
\text { following applies: If there are many guests, in general, the } \\
\text { number of goats that is slaughtered is only one; if the } \\
\text { number of guests is small, generally two are cut. }\end{array}$ \\
\hline III & $\begin{array}{l}\text { For the marriage ceremony among the Rejang people } \\
\text { apply: if the marriage is carried out according to the rules } \\
\text { of Islamic marriage, then the number of goats that is } \\
\text { slaughtered is one of the weddings is not following the } \\
\text { rules of Islamic marriage, then the number of goats that is } \\
\text { killed is two. }\end{array}$ \\
\hline IV & $\begin{array}{l}\text { For the marriage ceremony among the Rejang people } \\
\text { apply. If the marriage is carried out according to the } \\
\text { applicable marriage customary rules, then the number of } \\
\text { goats slaughtered to formalise one tail if there is a } \\
\text { marriage that violates the applicable marriage standard } \\
\text { rules, then the number of goats that must be killed to } \\
\text { inaugurate two. }\end{array}$ \\
\hline
\end{tabular}

Examining the legal issues of Baiq Nuril and Fidelis in a constructivist framework will move from the understanding that facts should not be reduced to things that can be observed but must be understood comprehensively, which includes intangible mental constructions from individual subjective experiences. Law is no longer just the application of the elements of articles of legislation but the law as a process of interpretation of relationships that take place intensively and extensively. Therefore, the law is jointly constructed by all interested parties without denying their respective subjectivity.

As an illustration, the facts of Baiq Nuril are as follows: The chronology of the problem began in 2012, where Baiq Nuril was still an Honorary Employee at SMAN 7 Mataram. One time he was called by $\mathrm{M}$. The conversation between $\mathrm{M}$ and Baiq lasted for about 20 minutes. Of the 20 minutes of discussion, only about 5 minutes of talking about work. The rest, $\mathrm{M}$ instead spoke about his sexual experiences with a woman who was not his wife. The conversation continues with tones of abuse towards Baiq.

Moreover, $\mathrm{M}$ called Baiq more than once. Baiq also felt annoyed and felt verbally abused by $\mathrm{M}$. Not only that, people around him accused him of having an affair with M. Feeling embarrassed by all of this, Baiq took the initiative to record his conversation with $\mathrm{M}$. This was done to prove that he had no relationship with his 
superior. However, Baiq never reported the recording for fear that his job would be threatened.

However, he spoke to Imam Mudawin, Baiq's colleague, about the recording. However, the recording was distributed by Imam to the Mataram Youth and Sports Agency (Diaspora). It is known that the submission of the recorded conversation with M Baiq was only made by giving a cellphone. The Imam entirely carries out transferring recordings from cell phones to laptops and other hands. Many people did not accept his disgrace to be heard; $M$ also reported Baiq to the police based on Article 27 Paragraph (1) of the Law on Electronic Information and Transactions (ITE). Even though the Imam distributed the recording, it was Baiq whom $M$ reported.

Normative Premise: Anyone who knowingly and without rights distributes and transmits and makes accessible Electronic Information and Electronic Documents that have contents that violate decency; (Article 27 (1) Law No. 11 of 2008 concerning ITE); Every person who fulfils the elements as referred to in Article 27 paragraph (1), paragraph (2), paragraph (3), or paragraph (3) shall be sentenced to imprisonment for a maximum of 6 (six) years or a maximum fine of IDR 1,000,000. .000 .00 (one billion rupiahs); (Article 45 (1) of the ITE Law);

Judges as stated in the Cassation Decision Number 574 K / Pid. Sus / 2018 assessed that Baiq Nuril was declared proven to have fulfilled the offence element in Article 27 paragraph (1) in conjunction with Article 45 paragraph (1) of Law Number 11 of 2008 concerning Electronic Information and Transactions. Of course, if we look at the Baiq Nuril case positivistically, the facts that Baiq Nuril do can qualify as meeting the elements in the provisions of the Article of the ITE Law, but if we use a comprehensive understanding which looks at matters relating to subjective intentions and facts that are not visible. Therefore, some initial ideas can be formulated, namely:

Idea 1: Baiq Nuril made the recording of the conversation to defend his pride from harassment and respond to allegations of cheating from his co-workers

Proposition 2: Baiq is not a person who deliberately distributes and or transmits information or electronic documents that have content that violates decency

Idea 3: Baiq's purpose in sharing his cell phone recordings with other co-workers is to serve as evidence against Baiq Nuril's sexual harassment.

In an illustration of the case experienced by Fidelis, the facts: That around 2013, Fidelis' wife experienced paralysis in her right leg, which in the end a year continued, both legs were paralysed. Due to not being cured after being given medical or non-medical treatment, the wife was only treated at home. Seeing that his wife's condition was not improving, Fidelis tried to find various alternative therapies and information from multiple references, books, and the internet. From some of these sources of information, we can get the properties of marijuana to help treat, thus encouraging Fidelis to try to find out more about how to obtain and buy marijuana.

Then around April 2016, Fidelis ordered an ounce of marijuana by paying Rp. 
900,000, - (nine hundred thousand rupiah) wherein less than 3 (three) days the order of marijuana and flower seeds is received by Fidelis. Through various compounding efforts, his marijuana treatment has had a significant impact on his wife's illness. However, in 2017, through public information, Fidelis was taken to the Sanggau Regency BNN office for interrogation, and at that time, Fidelis admitted that he deliberately planted marijuana for the treatment of his wife was seriously ill. Based on the drug test results on Fidelis' urine, the effects were adverse, while his wife's urine test was positive.

Normative Premise: Everyone who without rights or against the law plants, maintains, owns, keeps, controls, or provides Narcotics Category I in the form of plants shall be punished with imprisonment for a minimum of 4 (four) years and a maximum of 12 (twelve) years. and a minimum fine of Rp. 800,000,000.00 (eight hundred million rupiahs) and a maximum of Rp. 8,000,000,000.00 (eight billion rupiah). (Article 111 (1) Law No. 35 of 2009); Any person who without right or against the law uses Narcotics Category I against other people or gives Narcotics Category I for the use of other people, shall be punished with imprisonment for a minimum of 5 (five) years and a maximum of 15 (fifteen) years and a fine of at least Rp1,000,000,000.00 (one billion rupiahs) and a maximum of Rp.10,000,000,000.00 (ten billion rupiahs) (Article 116 (1) of Law No. 35 of 2009);

The judge considered that all the elements of Article 116 paragraph (1) of the Narcotics Law had been fulfilled, of course, if we only applied the law in the Fidelis Case positivistically, the facts carried out by Fidels could be qualified to meet the elements in the provisions of the Article of the Narcotics Law, but if we use the understanding that comprehensive which examines matters relating to subjective intentions and facts that are not visible. Therefore, some initial ideas can be formulated, namely:

Idea 1: Fidelis has never been involved in the circulation of narcotics of this type of marijuana and has never used drugs for his consumption;

Idea 2: Fidelis only uses Narcotics to treat his wife for Syringomyelia.

Proposition 3: In the wife's worsening condition, sanctions against Fidelis are imprudent and fair.

The ideas described to understand the problems that befell Baiq Nuril and Fidelis, not just without legal considerations or legally cannot be realised. Whereas in the perspective of criminal law, according to E. Utrecht's opinion, justifying reasons (Rechtvaardigingsgronden) are regulated, namely the reasons for eliminating wederrechtelijkheid and shculduitsluitingsgronden (reasons that eliminate mistakes in the broad sense of the word) only eliminating the responsibility (toerekenbaarheid) of the maker for the events he took place. It is generally accepted that the opinion that Rechtvaardigingsgronden abolishes a criminal possibility, namely the behaviour concerned, is not a criminal event even though it is following the painting of particular conduct prohibited in the criminal law. In contrast, in schulduitsluitingsgronden, the behaviour concerned is still a criminal event but cannot be accounted for (toegerekend) by the maker (Frans, 2012). 
According to Muljatno, the justification reason is an excuse that can eliminate the unlawful nature of an act so that what Fidelis does then becomes an appropriate and justified act. The reasons for removing crimes in law are also known as reasons for eliminating crimes outside the law. According to him, we should accept the existence of reasons for removing criminal offences outside the law, where the source is customary law, customary law, other norms not listed in the law.

The ideas mentioned above are an attempt to understand (verstehen) and interpret the goal of Baiq Nuril and Fidelis' actions. Every act (actus) carried out by every person must be understood to the deepest or hidden layer, namely the subjective motivations behind his actions. Understanding cannot be done only by seeing the outer layer visible, but it takes effort to penetrate the inner layer. Law enforcers, especially judges, are required to ultimately involve themselves when making decisions, relying on their proficiency in legislation and placing themselves in the law, considering that law is not merely a regulation but also behaviour (Eman, 2012).

Judges should have a constructivist view through hermeneutic techniques to understand the concept of truth, and objectivity needs to be improved. Objective truth, which has been understood as truth based only on empirical facts and prevailing normative laws, requires reconstruction through a general and comprehensive human collective understanding. This understanding is based on the principle of incomprehension between knowing something and giving an assessment (valuation) and the necessity to link understanding efforts with a broad context to develop understanding. Whereas legal norms, namely legislation, cannot just be proven inductively, and every fact cannot be shown deductively incorrect. Thus, it is necessary to have a comprehensive collective understanding for every law enforcer in deciding the truth of every act committed by the community.

Constructivists provide a more precise understanding of law in seeing law as a means of social control. The law will come alive if every problem in society can be interpreted and understood interactively as human facts. Based on collective understanding and awareness, objectives that are the essence of law can be obtained, namely the ideal legal values.

\section{CONCLUSION}

Based on the analysis and discussion above, this article concludes that law enforcement in the case of Baiq Nuril and Fidelis Arie is still determined by the very legalistic paradigm of positivism and legal positivism. Facts in the social life of society are reduced to observable facts; they are always looking for mistakes so that legal elements can be applied that can punish these actions. Positive law that is value-free can only be read flatly without trying to find the essence of the law, which should be a condition of adequate meaning and values in social life. The roles of law enforcers, police and judges are limited by distance, must be free from interests and leave behind emotions or concerns to decide an objective truth.

The law must be separated from moral arguments; thus, the legal discovery 
methodology carried out by law enforcers and experts is always guided by the applicable law as a product of authorised power that contains explicit orders that are positively formulated in statutory regulations. In the end, law enforcement officials tend to make the law a primum remedium so that the law has the potential to be applied excessively (overspanning van het straftrecht). The law should be the "last remedy" (ultimum remedium) as the final sanction to be used when other sanctions are considered insignificant.

Legal reconstruction can be pursued through legal constructivism paradigmshifting. Constructivism understands that every reality of every action (actus) that each person carries out must be understood to the deepest or hidden layer, namely the subjective motivations behind his actions. Understanding cannot be done only by seeing the outer layer, which is visible, but it takes effort to penetrate the inner layer.

Law enforcers must view reality as conceptual reality by making ideas as hypotheses to understand truth. Through hermeneutic techniques, objective truth, which has been understood as truth based only on empirical facts and prevailing normative laws, reconstruction is needed through a general and comprehensive human collective understanding.

Regarding the cases of Baiq Nuril and Fidelis, it is necessary to understand (verstehen) and interpret the reasons and goals of their actions with principles based on the inseparability of efforts to recognise intentions or goals and provide an assessment so that they can understand the broad context are. To develop understanding. Law enforcers are not supposed to apply legal norms. Namely, legislation is inductively proven to be accurate, and every fact is shown to be deductively incorrect.

\section{REFERENCES}

1. Ardhiwisastra, Y. B. (2000). Penafsiran dan Konstruksi Hukum. Bandung: Alumni.

2. Awuy, T. F. (1994). Menolak Logosentrisme, Merayakan Perbedaan. Jakarta: Kalam.

3. Chalmers Alan, F. (1999). What is a thing called science? St. Lucia: University of Queensland Press.

4. Guba, E. G., Lincoln, Y. S., \& Denzin, N. K. (1994). Handbook of Qualitative Research. Califónia: Sage Publication.

5. Hakim, A. (2017). Menakar Rasa Keadilan Pada Putusan Hakim Perdata Terhadap Pihak Ketiga Yang Bukan Pihak Berdasarkan Perspektif Negara Hukum Pancasila. Jurnal Hukum dan Peradilan, 6(3), 361-378.

6. Harris, C. D. (1986). Dictionary of Human Geography. Oxford: Basil Blackwell.

7. Hermansyah, H. (2009). Pendekatan Hermeneutik Dalam Penegakan Hukum (Upaya Dekonstruksi Terhadap Positivisme Hukum). Jurnal Dinamika Hukum, 9(3), 215-223.

8. Indarti, E. (2010). Diskresi dan Paradigma: Sebuah telaah filsafat hukum.

9. Irianto, S. (Ed.). (2009). Metode Peneltian Hukum: Konstelasi dan Refleksi. Jakarta: Yayasan Pustaka Obor Indonesia.

10. Lathif, N. (2017). Teori Hukum Sebagai Sarana Alat Untuk Memperbaharui Atau 
Merekayasa Masyarakat. Pakuan Law Review, 3(1).

11. Lisdiyono, E., \& Mulyani, S. (2021). Implications of Legal Positivism on Cybercrime Law Enforcement in Indonesia in the Case of the Hacking of the Mojokerto City Government Website. International Journal of Criminology and Sociology, 10, 891-896.

12. Maramis, F. (2012). Hukum Pidana umum dan tertulis di Indonesia. Jakarta: RajaGrafindo Persada.

13. McCoubrey, H. (1999). Textbook on jurisprudence. London: Blackstone Press Limited.

14. Prasetyo, T. (2020). Initiating Law Reform in Indonesia (From the Dignified Justice Perspective). Jurnal Hukum Magnum Opus, 3(1), 14-25.

15. Republic of Indonesia, Supreme Court. Sanggau District Court Decision Number: 111 / Pid.Sus / 2017 / PNSag Concerning the Prohibition of Using Cannabis as Treatment.

16. Roman, E. (1998). Reconstructing Self-Determination: The Role of Critical Theory in the Positivist International Law Paradigm. U. Miami L. Rev., 53, 943.

17. Rustamaji, M. (2015). Prison of Legal Positivism Paradigm and Corruption Eradication in Indonesia. Journal of Law, Policy and Globalisation, 35.

18. Samekto, F. (2012). Menggugat Relasi Filsafat Positivisme Dengan Ajaran Hukum Doktrinal. Jurnal Dinamika Hukum, 12(1), 74-84.

19. Sarmadi, A. S. (2012). Membebaskan Positivisme Hukum Ke Ranah Hukum Progresif (Studi Pembacaan Teks Hukum Bagi Penegak Hukum). Dinamika Hukum, 12(2), 331-343.

20. Shidarta. (2013). Hukum Penalaran dan Penalaran Hukum. Yogyakarta: Genta Publishing.

21. Sinaga, H. D. P. (2018, July). Reorientation of Tax Legal Certainty in Indonesia: An Exploration of Transcendental Law. In 1st International Conference on Indonesian Legal Studies (ICILS 2018) (pp. 282-287). Atlantis Press.

22. Siswomihardjo, K. W. (1982). Arti" perkembangan" menurut filsafat positivisme Auguste Comte dengan summary (Doctoral dissertation, [Yogyakarta]: Universitas Gadjah Mada).

23. Soeprapto, M. F. I., \& Attamimi, A. H. S. (1998). Ilmu Perundang-undangan: Dasardasar dan pembentukannya. Yogyakarta: Kanisius.

24. Sulistyawan, A. Y. (2019). Time for Punishment with Subjectivity: Study Philosophy of Law. Walisongo Law Review (Walrev), 1(1), 17-32.

25. Suparman, E. (2012). Pendistribusian Keadilan Oleh Pengadilan Serta Budaya Hukum Dalam Penyelesaian Sengketa. Jurnal Hukum dan Peradilan, 1(3), 399-416.

26. Tamanaha, B. Z. (2001). Socio-legal positivism and a general jurisprudence. Oxford Journal of Legal Studies, 21(1), 1-32.

27. Tamanaha, B. Z. (2007). The contemporary relevance of legal positivism. Austl. J. Leg. Phil., 32, 1.

28. The Republic of Indonesia. Law Number 11 of 2008 in conjunction with Law 19 of 2016 concerning Electronic Information and Transactions 
29. The Republic of Indonesia. Law Number 35 of 2009 concerning Narcotics

30. The Republic of Indonesia. Supreme Court. Cassation Decision Number 574 K/Pid.Sus / 2018 of the Republic of Indonesia. Supreme Court. Review Decision Number 83 PK / PID.SUS / 2019

31. The Republic of Indonesia. Supreme Court. Mataram District Court Decision Number 265 / Pid.Sus / 2017 / PN Mtr

32. Tjahjadi, S. L. (1991). Hukum moral ajaran Immanuel Kant tentang etika dan imperatif kategoris. Jakarta: BPK Gunung Mulia.

33. Tyesta, L. A., Saraswati, R., \& Arif, F. (2020). Implications of Legal Positivism of the Promotion of Children's Rights on National Law. J. Advanced Res. L. $\mathcal{E}$ Econ., 11, 661.

34. Utami, N. S., Suteki, S., Saraswati, R., \& Budiono, A. (2018). Faith In God, Independence Of Law And Independence Of Judges: Study Of Theistic Legal Realism In Legal Settlement. Justicia Islamica, 15(2), 195-208.

35. Widowati, C., \& Wijayanta, T. (2020). The Dialectic Study on the Legal Findings by the Judge as a Criticism and Support to Legal Positivism. Talent Development E Excellence, 12.

36. Wuisman, J. J. J. M. (1996). Penelitian Ilmu-ilmu Sosial Jilid 1: Asas-asas. Jakarta: Lembaga Penerbit FE-UI.

37. Zuliyah, S. (2019). The Importance Of Moral Values Through Law Enforcement In Indonesia In Nonsystematic Legal Approach. Journal of Transcendental Law, 1(2), 159-174.

38. Zuliyah, S., \& Triwahyuningsih, T. (2018, November). Moral Aspect in the Law Enforcement in Indonesia: Prophetic Perspective. In Annual Civic Education Conference (ACEC 2018). Atlantis Press.

39. 1945 Constitution of the Republic of Indonesia. 